\title{
On the law of radiation
}

\section{J. Violle}

To cite this article: J. Violle (1882) On the law of radiation, Philosophical Magazine Series 5 , 13:80, 225-227, DOI: 10.1080/14786448208627171

To link to this article: http://dx.doi.org/10.1080/14786448208627171

\section{曲 Published online: 28 Apr 2009.}

Submit your article to this journal ๘

Џll Article views: 2

Q View related articles ¿ 
The driving forward of the oxyhydrogen gas here supposed has also been assumed by Mallard and Le Chatelier*, in order to explain the increase of the velocity of propagation of the ignition observed by them.

From what has been adduced, it follows, inter alia, that in precise determinations of the heat of formation of water the $\mathrm{H}_{2} \mathrm{O}_{2}$ formed must also be taken into account, and, further, that, in the case of explosion, the loss of heat occasioned by the breaking must be taken into consideration.-Wiedemann's Annalen, 1882, no. 2, vol. xv. pp. 289-292.

ON THE LAW OF RADIATION. BY J. VIOLLE.

The intensity of a simple radiation emitted by incandescent platinum is very accurately represented by the formula

$$
\mathrm{I}=m \mathrm{~T}^{3}\left(1+\varepsilon \alpha^{-\mathrm{T}}\right)^{\mathrm{T}} \text {, }
$$

as I have previously pointed out, and as is proved by the following Table, which contains the values calculated by means of this formula for a portion of the measurements before mentioned :-

\begin{tabular}{|c|c|c|c|c|c|c|}
\hline \multirow{2}{*}{$t$. } & \multicolumn{2}{|c|}{$\lambda=656\left\{\begin{array}{l}\epsilon=0 \cdot 041495 \\
a=1 \cdot 00045\end{array}\right.$} & \multicolumn{2}{|c|}{$\lambda=589 \cdot 2\left\{\begin{array}{l}\epsilon=0.04295 \\
\alpha=1.00044 .\end{array}\right.$} & \multicolumn{2}{|c|}{$\lambda=535\left\{\begin{array}{c}\epsilon=0 \cdot 04467 \\
\alpha=1 \cdot 00043\end{array}\right.$} \\
\hline & $\begin{array}{l}\text { Calculated } \\
\text { intensities. }\end{array}$ & $\begin{array}{l}\text { Differences } \\
\text { from the } \\
\text { observed. }\end{array}$ & $\begin{array}{l}\text { Calculated } \\
\text { intensities. }\end{array}$ & $\begin{array}{l}\text { Differences } \\
\text { from the } \\
\text { observed. }\end{array}$ & $\begin{array}{l}\text { Calculated } \\
\text { intensities. }\end{array}$ & $\begin{array}{l}\text { Difference } \\
\text { from the } \\
\text { observed. }\end{array}$ \\
\hline $\begin{array}{r}775 \\
954 \\
1045 \\
1500 \\
1775\end{array}$ & $\begin{array}{c}1 \\
3 \cdot 1 \\
153 \\
501\end{array}$ & $\begin{array}{c}0 \\
-0 \cdot 2 \\
0 \\
-6\end{array}$ & $\begin{array}{c}0.05 \\
1 \\
3 \cdot 4 \\
218 \\
812\end{array}$ & $\begin{array}{c}0 \\
0 \\
-0 \cdot 2 \\
-1 \\
+3\end{array}$ & $\begin{array}{c}1 \\
36 \\
324 \\
1365\end{array}$ & $\begin{array}{c}0 \\
-\quad 0 \cdot 1 \\
+17 \\
0\end{array}$ \\
\hline
\end{tabular}

But if the attempt be made to represent by the same formula the numbers of Dulong and Petit relative to the radiation of their thermometer between $80^{\circ}$ and $240^{\circ}$, good results are not obtained. Nor does the celebrated formula of those two physicists, $I=m \alpha^{t}$, agree with the measurements obtained with incandescent platinum; and the expression $I=m T^{4}$, recently proposed by M. Stéphan, giving for the relative intensities at $954^{\circ}, 1045^{\circ}, 1500^{\circ}$, and $1775^{\circ}$ the numbers $1,1 \cdot 33,4 \cdot 36$, and $7 \cdot 73$, cannot be adopted.

On the other hand, a very satisfactory representation of the whole of the measurements is obtained by means of the formula

$$
\mathbf{I}=m \mathbf{T} b^{\mathbf{T}^{2}} \boldsymbol{\alpha}^{\mathbf{T}},
$$

in which $T$ represents the absolute temperature, $m$ a constant coefficient, $b$ the number $0.9999938, \alpha=1 \cdot 03550-13 \lambda, \lambda$ being the wave-length in millimetres.

In fact, if we apply this formula, first, to the platinum radiation, we shall have:-

* Comptes Rendus, xciii. pp. 146, 147 (1881).

Phil. Mag. S. 5. Vol. 13. No. 80. March 1882. 
Intelligence and Miscellaneous Articles.

\begin{tabular}{|c|c|c|c|c|}
\hline \multirow{2}{*}{$t$. } & \multicolumn{2}{|c|}{$\lambda=656}$. & \multicolumn{2}{|c|}{$\lambda=589 \cdot 2$} \\
\hline & $\begin{array}{l}\text { Calculated } \\
\text { intensities. }\end{array}$ & $\begin{array}{l}\text { Differences } \\
\text { from the } \\
\text { obs erved. }\end{array}$ & $\begin{array}{l}\text { Calculated } \\
\text { intensities. }\end{array}$ & $\begin{array}{c}\text { Differences } \\
\text { from the } \\
\text { observed. }\end{array}$ \\
\hline $\begin{array}{r}77 \hat{5} \ldots \ldots . \\
954 \ldots \ldots \\
1045 \ldots \ldots \\
1500 \ldots \ldots \\
1775 \ldots \ldots\end{array}$ & $\begin{array}{c}\dddot{1} \\
3 \cdot 0 \\
161 \\
507\end{array}$ & $\begin{array}{c}\ldots \\
0 \\
-0.3 \\
+7 \\
0\end{array}$ & $\begin{array}{c}0.04 \\
1 \\
3 \cdot 2 \\
219 \\
807\end{array}$ & $\begin{array}{c}-0.01 \\
0 \\
-0.4 \\
0 \\
-2\end{array}$ \\
\hline \multirow{2}{*}{$t$} & \multicolumn{2}{|c|}{$\lambda=535$} & \multicolumn{2}{|c|}{$\lambda=482$} \\
\hline & $\begin{array}{l}\text { Oalculated } \\
\text { intensities. }\end{array}$ & $\begin{array}{l}\text { Differences } \\
\text { from the } \\
\text { observed. }\end{array}$ & $\begin{array}{l}\text { Calculated } \\
\text { intensities. }\end{array}$ & $\begin{array}{l}\text { Differences } \\
\text { from the } \\
\text { observed. }\end{array}$ \\
\hline $\begin{array}{c}95{ }^{\circ} \\
1045 \ldots . . . \\
1500 \ldots . . . \\
1775 \ldots . .\end{array}$ & $\begin{array}{c}1 \\
344 \\
311 \\
1371\end{array}$ & 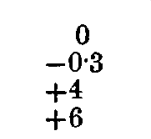 & $\begin{array}{l}142 \\
807\end{array}$ & $\begin{array}{l}1 \\
5 \cdot 7\end{array}$ \\
\hline
\end{tabular}

The calculations were made with the values of $\alpha$ which appeared to accord best with the observations. These values,

$$
1.02713, \quad 1.02772, \quad 1.02838, \quad 1.02935 \text {, }
$$

satisfy the formula $\alpha=1 \cdot 03550-13 \lambda$, with the respective differences

$$
-0.00016,+0.00012,+0.00015,-0.00012 \text {. }
$$

The experiments of Dulong and Petit are equally well represented by the same formula, assuming $\alpha=1 \cdot 01161$, - that is to say, supposing $\lambda=1838$, which is perfectly admissible according to the measurements of M. Mouton, who has determined the wave-

\begin{tabular}{|c|c|c|c|}
\hline \multirow[b]{2}{*}{ Excess. } & \multicolumn{2}{|c|}{ Velocity of cooling. } & \multirow[b]{2}{*}{$\Delta}$. \\
\hline & $\begin{array}{l}\text { Determined } \\
\text { by Dulong } \\
\text { and Petit. }\end{array}$ & $\begin{array}{l}\text { Calculated by } \\
\text { my formula. }\end{array}$ & \\
\hline $\begin{array}{r}80 \\
100 \\
10 . \\
120\end{array} \ldots . .$. & $\begin{array}{r}1 \cdot 74 \\
2 \cdot 30 \\
3 \cdot 02 \\
3 \cdot 88 \\
4 \cdot 89 \\
6 \cdot 10 \\
7 \cdot 40 \\
8 \cdot 81 \\
10 \cdot 69\end{array}$ & $\begin{array}{r}1 \cdot 71 \\
2 \cdot 35 \\
3 \cdot 10 \\
3 \cdot 97 \\
4 \cdot 96 \\
6 \cdot 10 \\
7 \cdot 39 \\
8 \cdot 84 \\
10 \cdot 46\end{array}$ & $\begin{array}{c}-0.03 \\
+0.05 \\
+0.08 \\
+0.09 \\
+0.07 \\
0 \\
-0.01 \\
+0.03 \\
-0.23\end{array}$ \\
\hline
\end{tabular}
lengths up to 2140 . Wo have, in fact:- 
The differences are not, in general, greater than those existiug between the numbers calculated by Dulong and Petit from theic formula and the observed numbers.

From the whole of these facts it appears to me to follow that, between $0^{\circ}$ and $1775^{\circ}$, the law of radiation can be represented by the formula

$$
\mathrm{I}=m \mathrm{~T} b^{\mathrm{T}^{2}} \alpha^{\mathrm{T}} \text {. }
$$

Comptes Rendus de l'Académie des Sciences, t. xcii. p. 1204.

ON WHEATSTONE'S BRIDGE. BY K. F. SLOTTE.

The length of the platinum wire belonging to this apparatus, which cannot be exactly determined by measurement, can, it is well known, be ascertained indirectly by comparing and exchanging resistances*. The following procedure is a modification of this method which may not be without advantages.

Let $s$ be the length of the wire, $a$ and $b$ that of its two divisions when two resistances $w_{1}$ and $w_{2}$ are inserted and the galvanometer shows no current. Then is

$$
\frac{w_{1}}{w_{2}}=\frac{a}{b}=\frac{s+a-b}{s-(a-b)}=\frac{s+d_{1}}{s-d_{1}}, \ldots \ldots \ldots
$$

in which $a-b$ is put $=d_{1}$. If now the resistances $v_{2}$ and $v_{2}$ be exchanged and the movable contact shifted till again no current passes through the galvanometer, this displacement, taken as positive or negative according to whether $a$ is more or less than $b$, is equal to $d_{1}$, which quantity can be directly determined by reading it off upon the scale of the apparatus.

If in the same manner $w_{2}$ be compared with a third resistance $w_{3}$, and, again, $w_{3}$ with $w_{1}$, aud if the displacements corresponding to $d_{1}$ be denoted respectively $d_{2}$ and $d_{3}$, then we bave

$$
\begin{aligned}
\frac{w^{2}}{w^{3}} & =\frac{s+d_{2}}{s-d_{2}}, \ldots \ldots \ldots \ldots \ldots \ldots \\
-\frac{w_{3}}{w_{1}} & =\frac{s+d_{3}}{s-d_{3}}, \ldots \ldots \ldots \ldots \ldots \ldots
\end{aligned}
$$

From (1), (2), and (3) we get

$$
1=\frac{\left(s+d_{1}\right)\left(s+d_{2}\right)\left(s+d_{3}\right)}{\left(s-d_{1}\right)\left(s-d_{2}\right)\left(s-d_{2}\right)}
$$

and finally, by solving the last equation,

$$
s=\sqrt{-\frac{d_{1} d_{2} d_{3}}{d_{1}+d_{2}+d_{3}}} \cdot \ldots \ldots \ldots \ldots \ldots
$$

Three determinations effected by this method, in which $w_{2}$ was chosen approximately equal to $\sqrt{w_{1} w_{3}}$, gave for $s$ the values $1118 \cdot 11$, $1118 \cdot 75,1118 \cdot 6$ millim.-Wiedemann's Annalen, 1882, no. 1, vol. xv. p. 176.

- See G. Wiedemann, Galvanismus, [2] i. p. 254. 